\title{
The Relation Between Fathering and School Children's Effortful Control: Moderating Effects of Parents' Effortful Control
}

\author{
Jaehee $\mathrm{Kim}^{1,2}$, Hyoun K. Kim ${ }^{3,4}$, Heesun Lee ${ }^{5}$ \\ Research Institute for Social Science, Ewha Womans University, Seoul, Korea ${ }^{1}$ \\ Graduate School of Social Policy, Gachon University, Seongnam, Korea ${ }^{2}$ \\ Department of Child \& Family Studies, Yonsei University, Seoul, Korea ${ }^{3}$ \\ Oregon Social Learning Center, Eugene, Oregon, U.S.A ${ }^{4}$ \\ Department of Early Childhood Education, Gachon University, Seongnam, Korea ${ }^{5}$ \\ 아버지 양육행동이 학령기 아동의 의도적 통제에 미치는 영향: \\ 아버지와 어머니의 의도적 통제의 조절효과를 중심으로 \\ 김재희 ${ }^{1,2}$, 김현경 3,4, 이희선,5 \\ 이화여자대학교 이화사회과학원 ${ }^{1}$, 가천대학교 사회정책대학원 ${ }^{2}$, 연세대학교 아동가족학과 ${ }^{3}$, \\ Oregon Social Learning Center ${ }^{4}$, 가천대학교 유아교육학과 ${ }^{5}$
}

Objective: This study examined whether the effects of fathering on school children's effortful control would be moderated by fathers' and mothers' own effortful control.

Methods: The sample included 371 fourth grade children ( $47 \%$ boys) and their parents. Father's positive and negative parenting behaviors, parents' own effortful control and children's effortful control were assessed. Data were analyzed using hierarchical multiple regression in SPSS 18.0.

Results: Parents' effortful control appeared to moderate the effect of fathering on children's effortful control. More specifically, parents' high levels of effortful control increased the effects of positive fathering on children's effortful control.

Conclusion: Findings indicated that parents' effortful control tended to increase the effects of positive fathering (and lower the effects of negative fathering). This supports the importance of parents' effortful control in the development of school children's effortful control.

Keywords: paternal effortful control, fathering, maternal effortful control, child's effortful control, moderating effect

\begin{abstract}
서론
인간은 사회생활 속 타인과의 끊임없는 관계에서 자신의 감 정이나 정서를 조절해야 하는 상황을 접한다. 정서조절능력 은 내적으로 각성되는 정서 상태로서 자신의 행동을 상황에

Corresponding Author: Jaehee Kim, Research Institute for Social Science, Ewha Womans University, \#11-1, Seodaemun-gu, Seoul, Korea E-mail: jaehee7750@hanmail.net
\end{abstract}

적절하게 표현함으로써 자신의 목적을 달성하고 긍정적인 사 회적 관계를 맺을 수 있도록 하는 자발적인 능력을 의미한다 (Eisenberg \& Spinrad, 2004). 이러한 개인의 정서조절능력은 사회적 행동에서 관찰되는 조절 행동과 부모의 보고나 자기보 고에 의해서 조사되는 기질적 의도적 통제 등 다양한 수준에

C)The Korean Association of Child Studies

This is an Open Access article distributed under the terms of the Creative Commons Attribution Non-Commercial License (http:// creativecommons.org/licenses/by-nc/4.0) which permits unrestricted noncommercial use, distribution, and reproduction in any medium, provided the original work is properly cited. 
서 조사되어 왔다(Rothbart \& Rueda, 2005). 개인의 기질은 각 개인에게 구분되어 특징적으로 나타나는 정서반응으로 인간 이 어떤 행동을 할 때 개인차가 드러나도록 하는 중요한 요인 이다. 이러한 기질을 구성하는 다양한 특성요인들 중, 자기 조 절적 요소를 반영하는 의도적 통제(effortful control [EC])는 외 부 자극에 대해서 자동적으로 발생되는 부적절한 반응을 줄이 는데 작동된다. 본인이 자발적으로 활성화시키는 의도된 통제 능력(EC)은 정서조절능력의 핵심 요소로서 연구자들에게 주 목 받고 있다(Bae \& Lim, 2011).

의도적 통제는 실행 주의력(executive attention)과 관련된 기 질의 하위 구성요소로서, 어떤 자극에 대해 반응적으로 발생 되는 상황에 적절하지 않을 수 있는 우세 반응을 억제시키고 우세하지 않은 적절한 반응을 수행하도록 활성화를 시키는 능 력으로 정의된다(Rothbart \& Bates, 2006). 동시에, 의도적 통제 는 자극에 대한 정서와 행동을 조절하여 반응적이고 충동적으 로 반응하기보다는 이를 의도한 목적에 따라 자발적으로 통제 하는 능력으로 정서조절의 핵심 요소로 간주된다(Eisenberg \& Spinrad, 2004). 즉 갈등상황에서 의도적 통제는 생리적으로 발 생되는 기분상태나 정서를 자신의 의지로 억제하거나 유지하 고 강도를 조절하며 긍정적 상태로 지속하는 과정을 뜻한다. 이러한 통제는 자신의 의지로 조절하는 것이므로 자극에 대한 자동적인 반응인 반응적 통제(reactive control)와 다르며 기존 연구에서 다루는 무조건적 억제에 따르는 자기조절과도 구분 된다(Eisenberg \& Spinrad, 2004).

의도적 통제는 타고난 기질적 요인을 토대로 사회 환경에 영향을 받아 발달하고(Eisenberg et al., 2003; Zhou et al., 2007), 뇌의 전두엽 발달의 영향을 받아 연령 증가에 따라 지속적으 로 성숙된다(Rothbart \& Posner, 2005). 의도적 통제는 그 자체 를 정서 조절능력이라고 볼 수는 없고, 자극에 대한 충동적인 우세한 반응을 자발적이고 계획적으로 억제하면서 바람직한 방향의 정서와 행동을 활성화하도록 조절하는 과정에서 작동 되는 실행기능이라고도 볼 수 있다(Eisenberg \& Spinrad, 2004; Garstein \& Fagot, 2003; Kochanska \& Knaack, 2003).

이러한 의도적 통제는 약 만 1 세 2세 정도에 형성이 되기 시작하여 유아기 시기에는 급속히 발달이 되고(Kochanska \& Knaack, 2003), 학령기에서 청소년기까지 환경의 영향을 받아 지속적으로 성숙한다(Eisenberg et al, 2005). 의도적 통제는 유 아기부터 성인기에 걸쳐 다양한 정서 기능, 대인관계, 공감능 력, 사회적 유능성, 문제행동, 학업 성취도 등과의 관련성이 있 는 것으로 밝혀져, 개인의 적응행동에 의미 있는 역할을 하는 것으로 밝혀졌다(Eisenberg et al., 2003; Eisenberg et al., 2009;
Valiente et al., 2006). 특히, 학령기 아동은 영아기, 유아기에 비 해 학교라는 환경에서 요구되는 사회적 규범에 대한 요구가 높아져, 잘 적응하기 위해서는 정교한 주의(attention)기능이 요구되고 충동적인 반응보다는 의도적인 통제가 활성화될 필 요가 있는 시기이다(Eisenberg et al., 2003). 또한, 학령기의 높 은 수준의 의도적 통제는 높은 수준의 학업 성취, 긍정적인 또 래 관계 형성, 사회적 기술 등 학교 적응에 대한 보호 역할을 하는 것으로 알려져 있다(Eisenberg et al., 2009; Valiente et al., 2006). 따라서 높은 수준의 의도적 통제 능력을 가진 학령기 아동은 학교생활의 전반적인 적응뿐만 아니라 이후 청소년기 의 문제행동으로 인한 부적응 가능성이 줄어들 것이다. 이에 학령기 아동의 의도적 통제에 영향을 미치는 요인간의 관계를 살펴보는 연구는 이후 청소년 시기의 부적응으로 이어질 수 있는 학령기 시기의 문제를 사전에 예방하기 위한 방안을 찾 는 데 필수적이라고 할 수 있다.

의도적 통제에 영향을 미치는 요인은 크게 환경적인 측면 과 유전적인 측면으로 구분되고, 이 두 측면의 상호작용에 의 해 발달된다(Rothbart \& Posner, 2005). 환경적인 측면 중 부모 와 관련된 요인은 가장 영향력이 높은 요인들 중 하나일 것이 다. 국외 선행연구들은 주로 부모의 정서 기능, 양육행동, 가 족환경의 질 등이 아동의 의도적 통제에 영향을 미치는 것으 로 보고하였다(Bridgett et al., 2011; Chang, Olson, Sameroff, \& Sexton, 2011; Eisenberg et al., 2001). 특히, 부모의 양육행동은 아동의 의도적 통제 발달에 대한 중요한 환경적 변인으로, 온 정적이거나 수용적인 긍정적인 양육행동 또는 강압적이고 처 벌적인 부정적인 양육행동에 따라 아동의 의도적 통제와 정 적 혹은 부적인 관계를 가지는 것으로 밝혀져 있다(Eisenberg et al., 2005; Karreman, Van Tuijl, Van Aken, \& Deković, 2008). 중국의 초등학생 저학년을 대상으로 조사한 Zhou, Eisenberg, Wang과 Reiser (2004)의 연구에 의하면, 부모가 언어적 적대 성을 보이고 체벌을 하는 권위주의적 양육을 할 때, 부모가 보 고한 아동의 의도적 통제 점수는 낮게 나타났다. 반면에 부모 가 온정적이고 수용적이며 논리적인 설명을 하는 민주적 양육 행동을 보였을 때 부모가 보고한 아동의 의도적 통제 점수가 높게 나타났다(Eisenberg, Chang, Ma, \& Haung, 2009). 부모양 육 이외에 아동의 의도적 통제에 영향을 미칠 수 있는 요인으 로는 부모의 개인적인 특성인 부모 스스로의 조절능력(혹은 의도적 통제능력)이 있다(Valiente, Lemery-Chalfant, \& Reiser, 2007). 유전에 의한 영향을 받는다고 밝혀진 의도적 통제의 특 성을 고려할 때, 부모의 의도적 통제는 세대 간 발생되는 유 전의 전이에 의해 아동의 의도적 통제와 관계할 것으로 가정 
할 수 있을 것이다(Calkins \& Hill, 2007; Mullineaux, DeaterDeckard, Petrill, Thompson, \& DeThorne, 2009). 아직까지 아동 의 의도적 통제에 관한 연구들은 부모의 양육행동 변인을 다 룬 연구들이 대부분이고 부모 자신이 지닌 의도적 통제의 영 향력을 파악한 연구는 충분하지 못한 실정이다.

한편, 기존의 관련 연구 대부분에서 부모의 영향력이라고 보고된 결과는 주로 어머니에 초점이 되어 연구되고 있다. 아 버지와 어머니는 가정이라는 맥락에서 아동에게 각각 직접적 영향을 미치는 미시체계 변인이다. 또한 아버지와 어머니 간 의 상호작용은 중간체계로서 아동발달에 중요한 역할을 함 에도 불구하고(Bronfenbrenner, 1986) 아버지와 어머니를 동시 에 다룬 연구보다는 어머니의 영향력을 부모의 영향력으로 일 반화시켜서 조사된 연구들이 대부분이다(Bridgett et al., 2011;

Chang et al., 2011; Eisenberg et al., 2001; Eisenberg et al., 2005). 현대 사회의 맞벌이 가정 증가는 공동 자녀양육자로서 아버지 의 역할과 자녀와의 상호작용이 강조되고 있는 상황이다. 그럼 에도 불구하고, 아동발달에 대한 아버지의 역할을 제대로 이해 할 수 있는 경험적 연구결과가 상당히 부족하다는 실정을 통 해서 아버지 역할에 대한 지속적인 연구가 필요하다는 것을 알 수 있다.

아동의 정서조절 능력에 대한 아버지와 어머니의 독립적인 영향력을 조사한 Cassano, Perry-Parrish와 Zeman (2007)의 연구 에 의하면, 아버지들은 자녀들의 슬픈 감정에 대해서 문제를 축소화시켜 자녀의 부정적 정서 표현을 억제시키는 반응을 하 는 것으로 나타났다. 반면에 어머니들은 자녀에게 문제를 해 결하는 전략을 알려주거나 슬픈 감정을 표현하도록 격려해주 는 반응을 사용하였다. 또한, 전반적으로 어머니가 아버지보다 아동의 정서 표현이나 정서 경험을 조절하는 능력에 더 커다란 영향을 미치는 것으로 밝혀졌으며(Fivush, Brotman, Buckner, \& Goodman, 2000; McDowell, Kim, O’neil, \& Parke, 2002) 이는 자 녀와 아버지와의 상호작용이 줄어드는 청소년기에는 더욱 두 드러지게 나타났다(Day \& Padilla-Walker, 2009). 이러한 연구결 과들은 어머니와 아버지가 자녀 발달에 각각 차별적인 고유한 영향력을 지니고 있음을 암시한다. 아버지들은 가정 수입의 주 책임자로서 어머니에 비해 상대적으로 여전히 가정에서 자녀 와 상호작용할 시간이 부족하고, 이로 인해 자녀양육에 참여 하는 시간이 부족한 실정이다(Ministry of Gender Equality and Family, 2016). 하지만, 최근 맞벌이 가정의 증가로 아버지들이 자녀의 교육에 관심을 가지고 어머니와 협력을 하고 있는 추세 라는 점(Shwalb, Nakazawa, Yamamoto, \& Hyun, 2004)과 위의 고찰한 연구결과를 고려한다면, 아버지의 아동의 발달에 대한
고유한 영향력이 어머니와 다르게 존재할 것을 기대하고 이를 구체적으로 파악해 볼 필요가 있다.

한편, 아동의 의도적 통제발달에 관한 국내 연구는 아직까 지 미흡한 실정이다. 아버지와 어머니의 의도적 통제가 부모 양육을 통해서 평균 27.8 개월의 영아의 의도적 통제에 미치는 영향을 조사한 Bae와 $\operatorname{Lim}$ (2012)의 연구에 의하면, 어머니의 의도적 통제와 달리 아버지의 의도적 통제는 영아의 의도적 통제에 미치는 영향이 유의미하지 않은 것으로 나타났다. 그 러나, 아버지의 애정적, 허용적 양육행동과 어머니의 애정적 인 양육행동은 유아의 의도적 통제와 상관하는 것으로 나타났 다(Bae \& Lim, 2015). 또한, 아버지가 배우자인 어머니로부터 지지와 격려를 받을수록 자녀를 공동으로 양육한다고 높게 지 각하고 이는 긍정적인 양육행동을 촉진시켜주는 것으로 나타 났다(Lim, Lee, \& Bae, 2015). 또한, 학령기 아동의 의도적 통제 에 대한 $\operatorname{Kim}(2015)$ 의 연구에서는 어머니와 아버지의 개인적 변인으로서 부모 자신들의 의도적 통제와 양육행동의 영향력 을 함께 조사하였는데, 어머니와 아버지가 서로 다른 양상으 로 영향을 미치는 것으로 나타났다. 어머니의 의도적 통제는 자신의 양육행동을 통해 아동의 의도적 통제에 영향을 주는 유의미한 매개효과를 보였으나 반면에, 아버지의 의도적 통제 는 아동의 의도적 통제에 직접적인 영향력을 보이지 않았다. 아버지의 양육행동은 어머니의 양육행동에 영향을 받아 아동 의 의도적 통제에 영향을 미치는 것으로 나타났다. 위에 살펴 본 선행연구들에 근거하여 아버지의 양육행동이 아동에게 미 치는 영향은 어머니의 특징에 의해서 영향을 받을 수 있는 가 능성과 아버지의 의도적 통제가 양육행동의 영향을 상호적으 로 조절하며 영향을 미칠 수 있는 가능성을 가늠해볼 수 있다.

위에서 고찰한 연구들에서 아동의 의도적 통제는 전반적으 로 부모 자신의 의도적 통제와 양육행동에 의해서 영향을 받 는 것을 확인할 수 있다. 특히 어머니의 의도적 통제능력은 아 동의 의도적 통제에 직접 혹은 간접적으로 영향을 주는 주요 변인으로 간주된다. 그런데, 아버지와 어머니의 영향을 부모 라는 공통변인이 아닌 고유한 영향으로 각각 고려해 볼 때, 어 머니와 아버지의 영향이 서로 다른 양상으로 나타날 수 있다 고 예상할 수 있다. 특히, 아버지의 의도적 통제의 영향이 어머 니의 영향에 비해 아동의 의도적 통제발달에 간접적이거나 혹 은 유의미하지 않게 나타난 기존의 연구결과에 대해서 구체 적으로 파악해 볼 필요가 있다. 아버지의 의도적 통제는 아동 의 의도적 통제에 유의미한 영향을 미치지 않는 변인인지 또 는 어머니와는 다른 방식으로 아동에게 영향력을 미치는지를 체계적으로 알아 볼 필요가 있다. 이를 위해서는 아버지와 어 
머니를 함께 조사하고 아버지와 어머니 각각의 양육행동과 의 도적 통제와 같은 부모의 개인적 특성 간에 드러나는 상호작 용을 살펴봄으로써 아버지의 양육행동이 자신의 의도적 통제, 그리고 어머니의 양육행동과 의도적 통제에 의해 어떻게 조절 되는지에 대한 명확한 근거를 얻는 노력이 필요하다.

인간의 다양한 사회정서행동 기능에 대한 선행변인으로 파 악된 의도적 통제는 함께 조사된 연구변인들에 따라 매개변 인으로 혹은 조절변인으로 조사되었다(Eisenberg et al., 2009; Lengua, Bush, Long, Kovacs, \& Trancik, 2008; Valiente et al., 2006). 의도적 통제가 조절변인으로 사용된 선행연구를 살펴보 면, 낯선 사람이나 대상에 대해 두려움을 표현하는 행동 억제 (inhibition)는 이후 성인기의 우울, 근심 또는 불안을 예측하였 으며, 의도적 통제는 이러한 행동억제의 부정적인 영향력을 줄 여주는 완충 역할을 하는 것으로 나타났다(White, McDermott, Degnan, Henderson, \& Fox, 2011). 의도적 통제가 낮은 청소년 의 경우 높은 수준의 부정적 정서성과 낮은 수준의 긍정적 정서 성을 보이면서 이는 우울 증상에 미치는 영향이 더욱 증가되는 것으로 나타났다(Verstraeten, Vasey, Raes, \& Bijttebier, 2009). 또 한, 8-12세의 초등학생 대상으로 조사한 Lengua 등(2008)의 연 구에서 이들의 사회 인구학적 취약성, 어머니의 우울과 정신적 문제, 가정환경 등의 위험요인들이 3년 동안 지속된 아동의 경 우, 이러한 위험요인들이 내재화 및 외현화의 문제행동에 미치 는 영향력은 아동의 의도적 통제 수준에 의해서 조절되었다. 그 런데, 의도적 통제의 조절효과는 위에서 살펴본 선행연구들과 같이 주로 아동이나 청소년 대상의 연구들이 대부분이었고, 부 모의 의도적 통제를 조절 변인으로 조사된 연구는 거의 없다. 그러나 의도적 통제가 인간의 사회정서행동 기능에 대한 예측 변인이라는 점은 성인에게도 적용이 되어, 부모의 의도적 통제 는 부모 양육행동이 아동에 미치는 영향에 대한 조절변인으로 작용할 수 있는 가능성을 생각해볼 수 있다. 특히 아버지의 생 계부양자로서의 역할로 인한 업무의 스트레스나 긴장은 자녀 와의 상호작용에 반영되기도 하며(Shwalb et al., 2004), 부모역 할 수행 시 자신의 감정을 감추거나 조절하고 자신의 즉각적 관심이나 욕구(예: TV 시청 등)를 억제하면서 기꺼이 자녀와 상 호작용에 초점을 두는 능력이 부족할 수 있다. 이러한 상황에 서 필요한 아버지의 능력은 우세한 반응을 억제하고 바람직한 반응으로 자발적으로 활성화시키는 의도적 통제와 관계할 것 이다. 따라서, 자녀에게 영향을 미치는 양육행동의 효과는 아버 지의 의도적 통제 능력 수준에 따라서 조절될 것으로 예측된다. 또한, 아버지의 영향은 공동양육이나 배우자 즉 어머니의 요 인 등에 더욱 영향을 받는 것으로 보고되어(Marsigilio, Amateo,
Day, \& Lamb, 2000; Stolz, Barber, \& Olsen, 2005) 어머니의 개인 적인 특성은 아버지의 양육행동을 긍정적으로 이끄는 역할을 할 가능성을 예측해볼 수 있다.

이렇듯 의도적 통제의 조절변인으로서의 가능성을 고려하 여, 본 연구에서는 아버지의 양육행동이 아동의 의도적 통제 에 미치는 영향력의 주효과와 그러한 아버지의 양육행동이 아 버지 자신의 의도적 통제능력에 의해 조절되는지를 살펴보고 자 한다. 또한, 선행연구(Kim, 2015; Stolz et al., 2005)에서 제시 된 결과를 토대로 아버지가 아동에게 미치는 영향에 있어서 어머니가 어떤 역할을 하게 되는지의 여부를 알아보기 위하 여, 아버지 양육이 아동의 의도적 통제에 미치는 영향을 어머 니의 의도적 통제 능력이 조절하는지를 조사하고자 한다. 최 근 우리나라 학령기 아동의 부적응이 증가되고 있다는 사회적 우려와 이를 예방하기 위한 교육이나 중재 프로그램의 필요성 을 고려하여, 본 연구에서는 학령기 아동의 전반적인 적응에 중요한 역할을 하는 의도적 통제 발달을 긍정적으로 이끌기 위한 부모의 역할 특히 그동안 간과되어 왔던 아버지의 올바 른 역할에 대한 정보를 제시하는데 목적을 둔다. 이에 본 연구 는 아동의 조절 아버지 교육을 돕는 프로그램 개발의 기초적 인 근거를 마련하는데 의의가 있을 것이다. 본 연구에서 설정 한 구체적인 연구문제는 다음과 같다.

\section{연구문제 1}

아버지의 양육행동이 아동의 의도적 통제에 미치는 영향을 아버지의 의도적 통제가 조절하는가?

\section{연구문제 2}

아버지의 양육행동이 아동의 의도적 통제에 미치는 영향을 어머니의 의도적인 통제가 조절하는가?

\section{연구방법}

\section{연구대상}

본 연구는 서울. 경기 지역 초등학교를 무작위로 5개 선정하 여 4학년 학생 409명과 그 부모를 대상으로 자료를 수집하였 다. 자료 수집은 선정된 초등학교의 담임교사를 통해 부모가 연구에 동의한 경우 가정에 설문지를 배부하고, 작성된 설문 지는 밀봉된 봉투에 넣어 다시 학교로 가져와 수거하는 방법 으로 실시되었다. 수거된 설문지 중에 아버지, 어머니, 아동이 
모두 답한 371명(약 91\%)만이 본 분석에 사용되었다. 연구 대 상에서 제외된 아동과 부모 집단은 분석에 사용된 연구대상과 조사된 변인들 간에 통계적으로 차이가 없는 동일한 집단임이 확인되었다 $(F=.02 \sim 3.31, p>.05)$. 연구대상 아동(남아, $47 \%)$ 의 평균 연령은 약 11 세 $(M=11.08, S D=3.7)$ 이고, 어머니는 평균 41.7세( $S D=3.59$, range 31-55), 아버지는 평균 44.3세 ( $S D$ $=3.59$, range 37-67)로 나타났다. 대상 가족의 경제적인 수준 은 전체의 약 $80.7 \%$ 가 월수입 500 만원 이상 $(M=732.37, S D=$ 570.22 )인 것으로 나타났고, 어머니는 약 $77 \%$ 가, 아버지는 약 $86.6 \%$ 가 대학졸업 이상의 교육수준이었다. 어머니의 과반수 (58.1\%) 이상은 전업주부였고, 아버지는 회사원, 공무원, 은행 원 등이 $39.1 \%$ 로 가장 많았으며, 전문직과 고위직이 그 다음 순으로 나타나 본 연구 대상은 중산층 이상의 가정에 속하는 것을 알 수 있다.

\section{측정도구}

본 연구는 부모의 의도적 통제, 부모의 양육행동, 아동의 의도 적 통제 3 가지 도구를 사용하였고 이를 구체적으로 살펴보며 다음과 같다.

\section{부모의 의도적 통제}

아버지와 어머니의 의도적 통제는 Rothbart와 Derryberry에 의해 개발된 Adult Temperament Questionnaire (ATQ) 중 의도 적 통제를 측정할 수 있는 총 19문항들을 사용하였다(Evan \& Rothbart, 2007; Rothbart, Ahadi, \& Evans, 2000). 억제 통제 (inhibitory control)는 7문항으로 구성되어 자신의 행동을 조절 하는 능력을 의미하고, 문항의 예는 "활기차 있을 때에도 필요 하다면 큰 문제없이 가만히 앉아 있을 수 있다.”, "재미있지만 부적절할 수 있는 행동을 쉽게 억제한다.” 등이다. 활성화 통 제(activation control)는 7문항으로 구성되어 회피하고 싶은 특 정 일이나 행동을 수행할 수 있는 능력을 의미하고, 그 문항의 예는 “별로 해 보고 싶지 않은 어려운 일도 할 수 있다.", "어떤 상황의 결과가 어떨지 걱정될 때, 보통 그 일을 다루지 않고 피 한다.” 등이다. 마지막으로 주의 통제(attentional control)는 5 문항으로 구성되어 요구될 때에는 주의를 지속하거나 전환할 수 있는 능력을 의미하고, 그 문항의 예는 "방해받거나 산만할 때, 보통 이전에 하고 있던 일로 주의를 쉽게 되돌릴 수 있다.”, "괴로울 때, 주의를 집중하는 것이 매우 힘들다." 등이다. 부모 의 의도적 통제를 측정하기 위한 세 가지 구성요소는 대부분
선행연구들에서 사용되고 있는 의도적 통제 척도의 지표이다 (Bae \& Lim, 2012; Bridgett, Burt, Laake, \& Oddie, 2013). 각 문 항은 Likert식 5점 척도로 구성되었으며, 하위요인의 평균점수 가 높을수록 의도적 통제수준이 높음을 의미한다. 본 연구에 서 산출된 ATQ의 의도적 통제 문항의 신뢰도(Cronbach's $\alpha$ )는 어머니의 경우 .79 로, 아버지의 경우 .75로 나타났다.

\section{부의 양육행동}

아버지의 양육행동은 Rhee와 Doh (2012)가 개발한 부모양육 척도로 온정 9문항, 논리적 설명 10 문항, 개입 9문항, 강압 7 문 항으로 측정하였다. 온정은 자녀에게 친밀하게 애정을 표현하 는 수용적인 양육을 의미하고 논리적 설명은 분명하고 합리적 인 기준과 이유로 잘못된 행동을 지도하고 설명해주는 양육을 의미한다. 반면에 개입은 부모의 뜻대로 행동하지 않을 경우 비난하고 간섭, 지시하는 양육행동을 의미하고 강압은 자녀를 벌주거나 체벌하는 양육행동을 의미한다. 각 문항은 Likert식 5 점 척도 $(1=$ 거의 그렇지 않다; 5 =매우 그렇다 $)$ 로 구성되었다. 내적합치도인 신뢰도(Cronbach's $\alpha$ )는 온정은 .81, 논리적 설명 은 .92, 개입은 .90, 강압은 .91으로 타나났다. 한편, 온정과 논리 적인 설명 $(r=.61, p<.000)$, 개입과 강압 $(r=.67, p<.000)$ 은 높 은 상관관계를 보여 두 변수를 통합하여 각각 긍정적인 양육 과 부정적인 양육으로 명명하고 분석하였다. 온정과 논리적 설 명의 평균의 합, 개입과 강압의 평균의 합이 높을수록 각각 긍 정적인 양육과 부정적인 양육을 많이 하는 것을 의미한다.

\section{아동의 의도적 통제}

아동의 의도적 통제는 학령기 아동의 기질 척도인 Temperament in Middle Childhood Questionnaire (TMCQ) 중 의도적 통제를 측정하는 주의력 집중(attentional focusing) 7문항과 억제통제 8 문항으로 측정하였고(Simonds, Kieras, Rueda, \& Rothbart, 2007), 아버지와 어머니가 각각 보고하였다. 본 연구 대상의 아동은 자 기보고식 조사가 가능함에도 불구하고 부모의 평가를 사용하 였다. 그 이유는 TMCQ 질문지를 사용한 선행연구에서 부모가 평가하는 것이 아동의 자기보고식 조사보다 측정의 신뢰도가 높다는 근거에 의해 부모가 보고하도록 하였다(Simonds et al., 2007; Simonds \& Rothbart, 2004).

주의 집중은 주의가 필요한 과제나 해야 하는 일에 계속해 서 집중할 수 있는 능력을 의미하며 그 문항의 예는 “집중하 는 것을 힘들어한다.” 등이다. 억제통제는 자신의 행동을 조절 
할 수 있는 능력을 의미하며 문항의 예는 "하던 일을 아주 빠 르게 멈출 수 있다.”, “흥분되었을 때에 말할 차례를 기다리는 것을 힘들어한다.” 등이 포함된다(Spinrad et al., 2006). 주의 집 중과 억제 통제는 학령기 아동 대상의 선행연구들에서 의도적 통제의 핵심 구성요소로 간주되어 Eisenberg와 동료들의 연구 에서 타당도와 신뢰도가 검증된 도구로 자주 사용되어져 왔다

(Geng, Hu, Wang, \& Chen, 2011; Zhou et al., 2007). 모든 문항 들은 5점 Likert식 척도(1점 = 거의 그렇지 않다; 5 점 $=$ 매우 그 렇다)로 측정하였고, 각 하위요인별 문항의 평균값이 분석에 사용되었으며 그 값이 클수록 의도적 통제 능력이 높은 것을 의미한다.

본 연구에서 부모가 보고한 아동의 의도적 통제의 신뢰도 는 어머니가 .89, 아버지가 .91로 확인되었고, 아버지와 어머 니의 보고 간에 상관관계가 억제 통제는 $r=.48$ ( $p<.001)$, 주 의 집중은 $r=.60(p<.001)$ 으로 높은 것으로 나타났다. 본 연 구에서는 다양한 보고자에 의한 보고 내용 (multi-informant approach)을 최대한 반영하고 변인 수를 줄이기 위해서 아버 지와 어머니가 보고한 각 하위요인의 평균점수를 사용하였다

(Eisenberg et al., 2009; Los Reyes, Thomas, Goodman, \& Kundey, 2013; Spinrad et al., 2006).

\section{자료분석}

본 연구의 자료는 PASW 18.0 (SPSS Inc., Chicago, IL)을 사용 하여 분석하였다. 먼저, 아버지의 의도적 통제, 어머니의 의도 적 통제, 아버지의 양육행동 및 부모보고의 아동의 의도적 통 제에 대한 평균 및 표준편차와, 전체 변인들 간의 관계를 알아 보기 위해서 Pearson 상관분석을 실시하였다. 아버지의 양육 행동이 아동의 의도적 통제에 미치는 영향이 아버지의 의도적
통제능력에 의해 어떻게 조절되는지, 그리고 아버지의 양육행 동이 아동의 의도적 통제에 미치는 영향에 대한 어머니의 의 도적 통제의 조절효과를 분석하기 위해서 위계적 중다회귀분 석(hierarchical multiple regression analysis)을 실시하였다. 회귀 분석을 통한 유의미한 상호작용 결과를 사후 검증하기 위해서 평균중심화한 $S D \pm 1$ 을 중심으로 상하 두 집단으로 나누어 회 귀식의 기울기의 상호작용에서의 유의성 검사를 통해 확인하 였다(Aiken \& West, 1991).

\section{연구결과}

\section{기초분석}

본 연구에서 조사된 어머니의 의도적 통제, 아버지의 의도적 통제와 긍정적. 부정적 양육행동 및 아동의 의도적 통제 변인 들 간의 평균과 표준편차는 Table 1 에 제시된 바와 같고, 그 상 관관계를 살펴본 결과 어머니와 아버지의 의도적 통제가 높을 수록 아동의 의도적 통제도 높은 것으로 나타났고, 아버지의 의도적 통제는 아버지 스스로의 긍정적 양육행동과는 정적 관 계를, 부정적 양육행동과는 부적인 관계를 가지는 것으로 나 타났다. 또한, 아버지의 긍정적·부정적 양육행동이 높을수록 아동의 의도적 통제는 높은 것으로 나타났다. 반면에 어머니 의 의도적 통제는 아버지의 의도적 통제와 긍정적인 관계, 양 육행동과는 정적인 관계를, 부정적인 양육행동에는 부적인 관 계를 보이는 것으로 나타났다. 이를 통해서 아버지 개인 내의 의도적 통제와 양육행동 간의 상호작용 혹은 어머니와 아버지 간의 상호작용이 아동의 의도적 통제에 미칠 수 있는 영향력 의 가능성을 확인하였다.

Table 1

Bivariate Correlations Among the Study Variables

\begin{tabular}{lccccc}
\hline & 1 & 2 & 3 & 4 & 5 \\
\hline 1. Maternal EC & - & & & & \\
2. Paternal EC & $.14^{* *}$ & - & & & \\
3. Positive fathering & $.14^{* *}$ & $.40^{* * *}$ & - & - & \\
4. Negative fathering & $-.14^{* * *}$ & $-.39^{* * *}$ & $-.40^{* * *}$ & - & - \\
5. Child's EC & $.26^{* * *}$ & $.35^{* * *}$ & $.43^{* * *}$ & $-.47^{* * *}$ & 3.47 \\
Mean & 3.68 & 3.65 & 7.43 & 4.51 & .49 \\
$S D$ & .41 & .42 & .93 & 1.26 & \\
\hline
\end{tabular}

Note. $N=371 . \mathrm{EC}=$ effortful control.

${ }^{* *} p<.01 .{ }^{* * *} p<.001$. 
아버지의 양육행동이 아동의 의도적 통제에 미치는 영향에 대한 아버지의 의도적 통제의 조절효과

연구문제 1 에 해당되는 아동의 의도적 통제에 미치는 아버지 의 양육행동의 영향을 아버지의 의도적 통제수준이 조절하는 지를 살펴보기 위해서 아버지의 양육행동을 긍정적인 양육행 동과 부정적인 양육행동으로 구분하여 각각 위계적 회귀분석 을 실시하였다. 회귀분석을 실시하기에 앞서 다중공선성의 문 제를 해결하기 위하여 평균중심화(mean centering) 변수 처리 를 하였고, Tolerance는 모두 절대값 1 에 가깝고 VIF값은 10보 다 작은 것을 확인하여 회귀분석의 전제 가정을 위배하지 않 음을 검증하였다.

아동의 의도적 통제 발달에 대해 긍정적 양육행동이 미치는 영향을 아버지의 의도적 통제가 조절하는 효과와 부정적 양육 행동이 미치는 영향을 아버지의 의도적 통제가 조절하는 효과 에 대한 회귀 분석 결과는 Table 2과 같다. 아버지의 긍정적인 양 육행동과 아버지의 의도적 통제가 아동의 의도적 통제 발달을 예측하는 주효과가 확인되었다(긍정적 양육 행동: $b=.18, t=$ $6.65, p<.001$, 아버지의 의도적 통제: $b=.25, t=4.26, p<.001)$.

또한, 아버지의 긍정적 양육행동의 영향을 아버지의 의도 적인 통제가 조절하는 것으로 나타났다. 아버지의 의도적 통 제가 긍정적 양육행동의 영향을 조절하는 모델은 주효과 모델 보다 $1 \%$ 증가된 $23 \%$ 변량을 갖는 것으로 나타났다 $(b=.10, t=$ $2.14, p<.001$; Table 2). 즉, 아버지의 긍정적인 양육행동이 아
동의 높은 의도적 통제를 예측하는 영향력은 아버지의 의도적 통제가 높은 집단일수록 그 효과가 더욱 증가하였다(Figure 1).

한편, 아버지의 부정적인 양육행동과 아버지의 의도적 통 제가 아동의 의도적 통제 발달을 예측하는 주효과가 확인 되었고, 그 결과는 Table 3 과 같다(부정적 양육행동: $b=-.15$, $t=-7.89, p<.001$, 아버지의 의도적 통제: $b=.22, t=3.91$, $p<.001)$. 또한 아버지의 부정적 양육행동이 아동의 낮은 의 도적 통제를 예측하는 영향은 아버지의 의도적 통제 수준이 높은 집단일 때만 그 효과가 증가되는 조절 효과가 나타났다

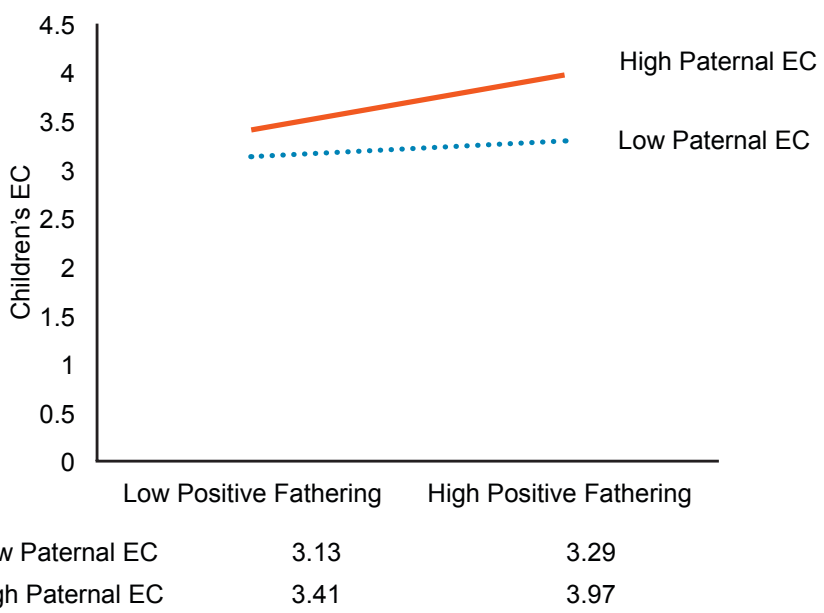

Figure 1. Effects of positive fathering on child's effortful control moderated by paternal effortful control. $\mathrm{EC}=$ effortful control.

Table 2

Effects of Positive Fathering on the Child's Effortful Control Moderated by Paternal Effortful Control

\begin{tabular}{|c|c|c|c|c|c|c|c|}
\hline & \multirow[b]{2}{*}{ Model } & \multicolumn{2}{|c|}{ Unstandardized } & \multirow{2}{*}{$\frac{\text { Standardized }}{\beta}$} & \multirow[b]{2}{*}{$t$} & \multirow[b]{2}{*}{ Tolerance } & \multirow[b]{2}{*}{ VIF } \\
\hline & & $B$ & $S E$ & & & & \\
\hline 1 & Positive fathering & .22 & .03 & .42 & $8.97^{* * *}$ & 1.00 & 1.000 \\
\hline \multirow[t]{2}{*}{2} & Positive fathering & .18 & .03 & .34 & $6.69^{* * *}$ & .84 & 1.19 \\
\hline & Paternal EC & .25 & .06 & .22 & $4.26^{* * *}$ & .84 & 1.19 \\
\hline \multirow[t]{4}{*}{3} & Positive fathering & .18 & .03 & .33 & $6.65^{* * *}$ & .84 & 1.19 \\
\hline & Paternal EC & .24 & .06 & .21 & $4.13^{* * *}$ & .84 & 1.20 \\
\hline & Positive fathering & .10 & .05 & .10 & $2.14^{* * *}$ & .99 & 1.01 \\
\hline & \multicolumn{7}{|c|}{$F=35.95, R^{2}=.23\left(\Delta R^{2}=.01\right)$} \\
\hline
\end{tabular}

Note. $N=371 . \mathrm{EC}=$ effortful control.

*** $p<.001$. 
Table 3

Effects of Negative Fathering on Child's Effortful Control Moderated by Paternal Effortful Control

\begin{tabular}{|c|c|c|c|c|c|c|c|}
\hline & \multirow[b]{2}{*}{ Model } & \multicolumn{2}{|c|}{ Unstandardized } & \multirow{2}{*}{$\frac{\text { Standardized }}{\beta}$} & \multirow[b]{2}{*}{$t$} & \multirow[b]{2}{*}{ Tolerance } & \multirow[b]{2}{*}{ VIF } \\
\hline & & $B$ & $S E$ & & & & \\
\hline \multirow[t]{2}{*}{1} & Negative fathering & -.18 & .02 & -.47 & $-9.98^{* * *}$ & 1.00 & 1.000 \\
\hline & \multicolumn{7}{|c|}{$F=99.46, R^{2}=.22\left(\Delta R^{2}=.22\right)$} \\
\hline \multirow[t]{3}{*}{2} & Negative fathering & -.15 & .02 & -.40 & $-7.89^{* * *}$ & .85 & 1.17 \\
\hline & Paternal EC & .22 & .06 & .19 & $3.91^{* * *}$ & .85 & 1.17 \\
\hline & \multicolumn{7}{|c|}{$F=59.35, R^{2}=.25\left(\Delta R^{2}=.03\right)$} \\
\hline \multirow[t]{4}{*}{3} & Negative fathering & -.15 & .02 & -.40 & $-8.04^{* * *}$ & .85 & 1.18 \\
\hline & Paternal EC & .21 & .06 & .18 & $3.73^{* * *}$ & .85 & 1.18 \\
\hline & $\begin{array}{l}\text { Negative fathering } \\
\times \text { paternal EC }\end{array}$ & -.09 & .04 & -.10 & $-2.20^{* * *}$ & .99 & 1.01 \\
\hline & \multicolumn{7}{|c|}{$F=.42, R^{2}=.26\left(\Delta R^{2}=.01\right)$} \\
\hline
\end{tabular}

Note. $N=371 . \mathrm{EC}=$ effortful control.

${ }^{* * *} p<.001$.

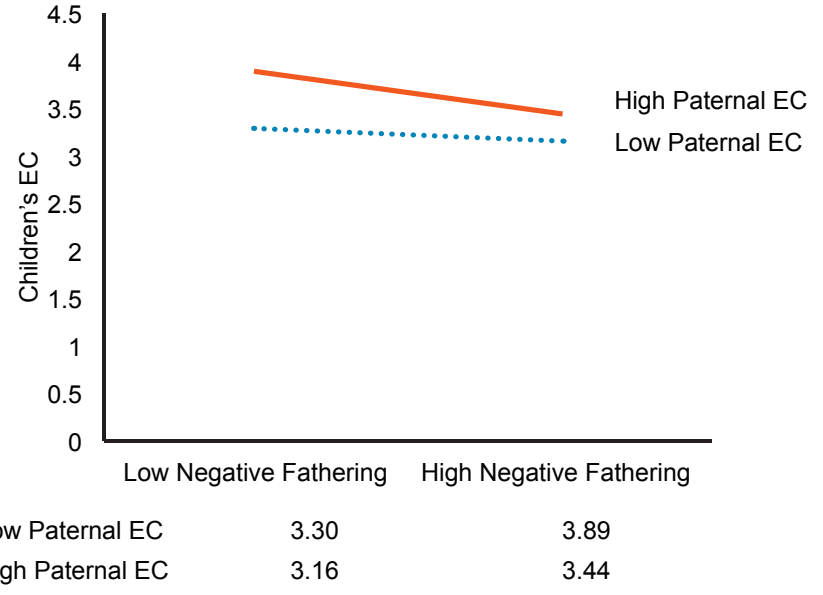

Figure 2. Effects of negative fathering on child's effortful control moderated by paternal effortful control. EC = effortful control.

( $b=-.09 . t=-2.20, p<.001)$. 이러한 조절작용 모델은 Table 3 와 같이 주효과 모델보다 $1 \%$ 증가된 $26 \%$ 의 설명력을 보였다. 즉, 아버지의 의도적 통제가 낮은 경우는 아버지의 부정적 양 육행동 수준과는 상관이 없이 아동의 의도적 통제 수준에 차 이가 거의 나타나지 않았다. 그러나, 아버지가 높은 수준의 의 도적인 통제를 가진 경우 낮은 수준의 부정적인 양육행동이 아동의 의도적 통제능력에 긍정적인 영향을 보였다. 즉, 아버 지의 부정적인 양육이 아동의 의도적 통제에 미치는 영향은 부정적인 양육의 정도가 낮을 때 그 효과가 더욱 드러나는 것 으로 나타났다(Figure 2).

\section{아버지의 양육행동이 아동의 의도적 통제에 미치는 영향에 대한 어머니의 의도적인 통제 의 조절 효과}

연구 문제 2 에 해당하는 아동의 의도적 통제에 미치는 아버지 의 양육행동의 영향에 대한 어머니의 의도적 통제의 조절효과 를 조사하기 위해서 아버지의 양육행동을 부정적, 긍정적 양육 행동으로 구분하여 조사하였다. 각각의 모델 중에 아버지의 긍 정적 양육의 영향을 어머니의 의도적 통제가 조절하는 모델만 이 유의미한 것으로 나타났고 상호작용의 효과에 대한 결과만 요약하여 제시하면 Table 4와 같다. 이러한 사전 분석을 통해서 본 연구에서는 아버지의 긍정적 양육과 어머니의 의도적 통제 의 상호작용적 관계를 포함한 모델의 결과만을 구체적으로 보 고하였다. 아버지의 긍정적 양육행동과 어머니의 의도적 통제 는 모두 아동의 의도적 통제를 예측하는 주효과가 나타났다. 아버지의 긍정적 양육 행동은 아동의 의도적 통제를 예측하는 데, 어머니의 의도적 통제 수준에 따라 그 효과가 다르게 나타 났다 $(b=.13, t=2.42, p<.001$; Table 5). 이러한 조절효과 모델은 주효과 모델보다 $1 \%$ 증가된 $24 \%$ 의 설명력을 가지는 것으로 나타났다. 즉, 아버지의 긍정적 양육행동이 아동의 의도적 통제 능력을 예측하는데 있어서, 높은 의도적 통제 능력을 가진 어머 니의 아동이 낮은 의도적 통제 능력을 가진 어머니의 아동보다 높은 수준의 의도적 통제능력을 가지는 것으로 나타나, 어머니 의 높은 수준의 의도적 통제 능력은 아버지의 긍정적인 양육의 영향력을 더욱 증가시키는 누적 효과가 나타났다(Figure 3). 
Table 4

Effects of Fathering on Child's Effortful Control Moderated by Maternal Effortful Control

\begin{tabular}{|c|c|c|c|c|c|c|}
\hline \multirow[b]{2}{*}{ Interaction } & \multicolumn{2}{|c|}{ Unstandardized } & \multirow{2}{*}{$\frac{\text { Standardized }}{\beta}$} & \multirow[b]{2}{*}{$t$} & \multirow[b]{2}{*}{$F$} & \multirow[b]{2}{*}{$R^{2}$} \\
\hline & $B$ & $S E$ & & & & \\
\hline $\mathrm{PF} \times \mathrm{MEC}$ & .13 & .06 & .11 & $2.42^{* *}$ & $38.36^{* * *}$ & .24 \\
\hline
\end{tabular}

Note. $N=371$. PF: positive fathering; NF: negative fathering; MEC: maternal effortful control.

${ }^{* *} p<.01 .{ }^{* * *} p<.001$.

Table 5

Effects of Positive Fathering on Child's Effortful Control Moderated by Maternal Effortful Control

\begin{tabular}{|c|c|c|c|c|c|c|c|}
\hline \multirow{2}{*}{\multicolumn{2}{|c|}{ Model }} & \multicolumn{2}{|c|}{ Unstandardized } & \multirow{2}{*}{$\begin{array}{c}\text { Standardized } \\
\beta \\
\end{array}$} & \multirow[b]{2}{*}{$t$} & \multirow[b]{2}{*}{ Tolerance } & \multirow[b]{2}{*}{ VIF } \\
\hline & & $B$ & $S E$ & & & & \\
\hline \multirow[t]{2}{*}{1} & Positive fathering & .23 & .03 & .43 & $9.17^{* * *}$ & 1.00 & 1.000 \\
\hline & \multicolumn{7}{|c|}{$F=84.14, R^{2}=.19\left(\Delta R^{2}=.19\right)$} \\
\hline \multirow[t]{3}{*}{2} & Positive fathering & .21 & .02 & .40 & $8.69^{* * *}$ & .98 & 1.02 \\
\hline & Maternal EC & .24 & .06 & .20 & $4.41^{* * *}$ & .98 & 1.02 \\
\hline & \multicolumn{7}{|c|}{$F=53.92, R^{2}=.23\left(\Delta R^{2}=.04\right)$} \\
\hline \multirow[t]{4}{*}{3} & Positive fathering & .21 & .02 & .41 & $8.80^{* * *}$ & .98 & 1.02 \\
\hline & Maternal EC & .22 & .06 & .19 & $4.07^{* * *}$ & .96 & 1.04 \\
\hline & Positive fathering & .13 & .06 & .11 & $2.42^{* * *}$ & .98 & 1.02 \\
\hline & \multicolumn{7}{|c|}{$F=38.36, R^{2}=.24\left(\Delta R^{2}=.01\right)$} \\
\hline
\end{tabular}

Note. $N=371 . \mathrm{EC}=$ effortful control.

*** $p<.001$.

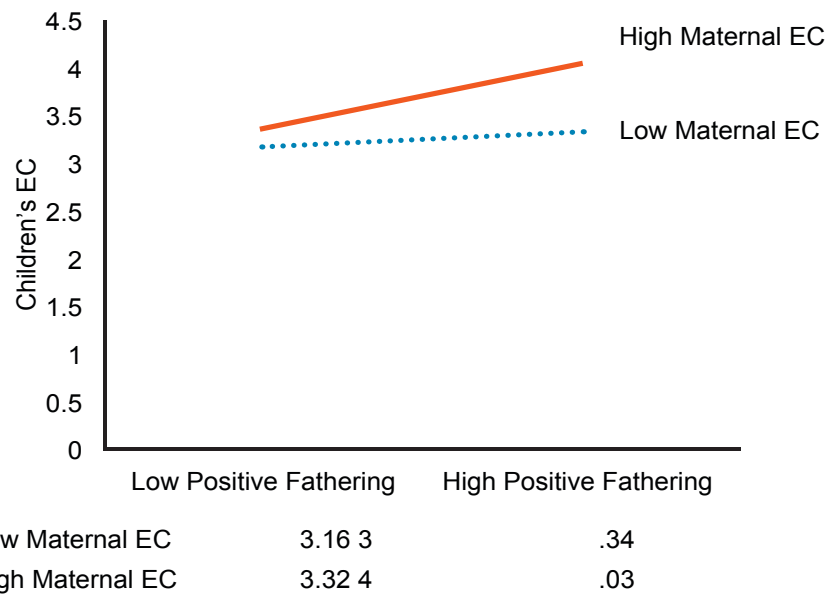

Figure 3. Effects of positive fathering on child's effortful control moderated by maternal effortful control. $\mathrm{EC}=$ effortful control.

\section{논의 및 결론}

본 연구는 초등학교 4학년 대상으로 아버지의 의도적 통제와 양육행동이 아동의 의도적 통제에 어떠한 방식으로 영향을 미
치는지 조사하고, 아버지의 양육행동이 아동의 의도적 통제에 미치는 영향을 아버지의 개인 내적 특성인 자신의 의도적 통 제가 어떻게 조절하는지를 밝히고자 하였다. 또한, 가정 내에 서 주 양육자인 어머니가 아버지의 양육행동에 영향을 미칠 수 있는 가능성을 고려하여 어머니의 의도적 통제와 양육행동 의 조절효과를 조사하였다. 이를 통해서 아동의 의도적 통제 발달을 지원하기 위한 방안을 탐색해보고자 하였다. 그 결과 아동의 의도적 통제는 아버지가 긍정적 양육을 하고, 낮은 수 준의 부정적 양육을 할수록 발달되고, 아버지의 의도적 통제 가 높을수록 그 효과는 증가되었다. 또한, 아동의 의도적 통제 는 아버지의 긍정적 양육을 높은 수준으로 할 때 발달되었고, 그 영향력은 어머니의 의도적 통제가 높을 때 증가되는 것으 로 나타났다.

본 연구의 주요한 결과에 대해서 구체적으로 요약하고 논 의하면 다음과 같다. 첫째, 아버지의 내에서의 영향만을 고려 하여 아버지의 양육행동과 의도적 통제가 상호작용하여 아동 의 의도적 통제에 미치는 효과를 살펴보았다. 우선, 아버지의 부정적 양육행동과 긍정적 양육행동의 아동의 의도적 통제에 대한 주효과가 나타났다. 아동의 의도적 통제 능력은 아버지 
가 개입이나 강압과 같은 부정적 양육에는 부적으로, 온정을 보여주고 친밀한 관계를 보이며 논리적인 설명을 주는 합리적 인 긍정적 양육과 아버지의 의도적 통제 능력에는 정적으로 영향을 받는 것으로 나타났다. 이는 아동의 정서조절 능력 즉 의도적 통제가 발달되기 위해서는 부모 스스로의 의도적 통 제 능력과 이와 더불어 수반되는 양육행동의 질이 중요하다고 밝힌 선행연구들과 일치한다(Bridgett et al., 2011; Chang et al., 2011; Eisenberg et al., 2001). 아동은 부모와의 끓임없는 상호작 용 맥락 속에서 자신의 정서와 행동을 조절하고 문제를 해결 해 나가는 방식을 학습하게 된다. 부모와 생활하는 환경 내에 서 발생하는 다양한 문제 상황에서 아동은 부모 스스로가 보 이는 정서행동과 대처 방식을 관찰하고 학습하여 정서 조절능 력을 내면화하게 된다(Valiente et al., 2007). 또한, 부모의 온정 적이고 혹은 애정적인 양육은 아동의 의도적 통제 능력을 촉 진시키고, 강압적으로 통제하는 방식의 양육은 의도적 통제 능력을 저하시킨다(Eisenberg et al., 2001).

또한, 아버지의 긍정적인 양육행동 혹은 부정적인 양육행 동이 아동의 의도적 통제에 미치는 효과는 아버지의 의도적 통제 수준에 따라서 달라지는 조절효과가 나타났다. 즉, 아버 지의 긍정적인 양육은 아버지가 높은 의도적 통제능력을 가지 고 있을 때 아동의 의도적 통제 능력에 대한 효과가 증가되는 것으로 나타났다. 반면에, 아버지의 부정적인 양육행동에 의 한 효과는 아버지의 의도적 통제 수준에 따라 다르게 나타났 는데, 아버지의 의도적 통제가 높은 경우 특히 아버지가 부정 적인 양육을 덜 할수록 아동의 의도적 통제 수준에 미치는 그 효과가 더욱 증가되었다. 즉, 아버지의 의도적 통제에 의한 조 절 효과는 아버지가 긍정적인 양육을 할수록, 또는 부정적인 양육의 정도가 낮을수록 그 효과가 더욱 드러나는 것으로 나 타났다. 전반적으로 아버지가 부정적인 양육을 하지 않을수록 아버지의 의도적 통제 능력 수준의 조절이 더욱 유의미하게 나타났다. 이는 아버지가 자녀를 강압적으로 대하거나 개입 을 지나치게 하는 것은 아동의 의도적 통제 발달을 방해하는 부정적인 위험요소로서의 역할을 강하게 하는 것으로 해석할 수 있다. 이는 중국 베이징 7-10세의 아동을 대상으로 부모의 양육유형과 아동의 의도적 통제 간의 관계를 조사한 Zhou와 동료들(2004)의 연구에서 아버지의 강압적, 적대적 권위주의 적 양육방식은 아동의 낮은 의도적 통제와 강한 관계가 나타 난 결과와 일맥상통한다. 또한, 몇 몇의 선행연구들(McDowell et al., 2002; McDowell \& Parke, 2000)에서 아버지와 아동의 상 호작용은 어머니와의 상호작용에 비해 정서적인 자극의 강도 가 보다 크고 정서의 흥분정도가 높은 경향이 있다고 보고하
고 있는데, 이는 아버지가 어머니보다 비난하거나 더 높은 강 도로 아동을 통제하게 될 가능성이 높아 아동이 부정적인 조 절 전략을 학습하는 효과가 더욱 드러나게 되는 것으로 해석 된다. 따라서, 이 과정에서 아버지가 의도적 통제 능력이 높다 면 부정적인 조절 전략이나 강압적인 방식을 덜 사용하게 되 고, 정서의 흥분 정도를 줄이는 기능이 더욱 효과가 드러나게 될 것으로 보인다.

일반적으로 아버지, 어머니 모두 자신이 지닌 정서조절능 력은 양육행동의 질에 영향을 준다(Bariola, Hughes, \& Gullone, 2012). 의도적 통제는 다양한 상황에서 충동적으로 발생하는 우세한 반응을 억제하고, 집중해야 하는 대상에 집중하면서 선호하지 않는 일임에도 불구하고 그 일을 할 수 있도록 자신 을 활성화시키는 능력이다(Eisenberg \& Spinrad, 2004; Rothbart $\&$ Bates, 2006). 따라서 부모의 의도적 통제는 양육 스트레스 부담으로 힘든 상황에 처하게 되면서 발생할 수 있는 부정적 감정이나 심리적인 갈등을 자신의 의지로 조절하여 자녀에게 긍정적인 환경을 제공한다는 측면에서(Calkins \& Hill, 2007; Garstein \& Fagot, 2003) 중요하다. 즉 부모의 의도적 통제 능력 은 양육 상황에서 자녀와 상호작용의 질에 영향을 미친다. 실 제로, 부모교육 현장에서 많은 부모들이 토로하는 어려움은 자녀 양육기술 교육을 받아도 가정에서 실천이 어려운 이유로 부모 스스로 정서조절을 못하고 충동적으로 문제를 해결하게 된다는 것을 토로하였는데, 이는 부모의 정서조절 능력의 중 요한 작용이 있음을 시사한다(Bridgett et al., 2013, 2011).

한편, 전통적인 한국문화에서 아버지는 어머니에 비해 정 서조절을 훈련받을 기회가 적고 어머니보다 강압적이고, 가정 내에서 힘을 행사하는 행동이 많은 가부장적 문화적 특수성이 나타난다(Lee \& Chyung, 2014). 만일 이러한 아버지의 특성이 아동에게 자연스럽게 받아들여진다면 강압적인 행동은 아동 에게 크게 영향을 미치지 않았을 수 있다. 그러나 의도적 통제 능력 수준이 높은 아버지는 자신의 부정적 행동, 충동성, 주의 집중 등을 통제하여 긍정적인 양육행동으로 아동과 함께 보낼 가능성이 높아진다. 이에 아동의 사회화에 영향을 미칠 수 있 는 아버지의 긍정적인 영향이 증가되는 효과가 나타난 것으로 추측해볼 수 있다. 종합적으로 정리하면, 아버지가 온정적이 고 합리적이고 논리적으로 설명하며 아버지 자신이 스스로 감 정과 행동을 잘 통제하고 주의집중을 하여 아동과 상호작용을 하면 아동의 높은 의도적 통제 능력을 가장 잘 예측할 수 있다. 반면에 아버지의 의도적 통제가 높음에도 불구하고 양육행동 이 강압적이고 통제적이면, 자녀의 의도적 통제에 미치는 부 적 영향을 완화시키지 못하는 것으로 보아, 아버지의 부정적 
인 양육행동을 감소시키는 것이 가장 중요하다. 또한, 높은 수 준의 의도적 통제 능력을 가진 아버지가 긍정적인 양육행동을 할 때 아동의 의도적 통제 발달은 더욱 향상 될 수 있음을 알 수 있다.

둘째, 아버지 양육행동이 아동의 의도적 통제에 미치는 영 향을 어머니의 의도적 통제가 어떻게 조절하는지를 조사하기 위해서 양육행동을 부정적, 긍정적으로 구분하여 각각 조사하 였다. 그 결과, 아버지의 긍정적 양육의 영향을 어머니의 의도 적 통제가 조절하는 경우만 유의미하게 나타났다. 이는 아동 의 의도적 통제 발달에 있어서 아버지의 긍정적인 영향은 어 머니가 높은 의도적 통제를 가지고 있을 때 더욱 증가되는 것 을 의미한다. 이는 아동의 정서 조절능력과 관련된 변인들은 아버지보다는 어머니와의 분명한 관계성이 드러났고, 아버지 와 아동의 관계에서 아버지의 영향력은 어머니와 달리 공동 양육이나 배우자 즉 어머니의 요인 등에 의해 더욱 영향을 받 는 것으로 보고된 선행연구들(Bariola et al., 2012; Karraman et al., 2008; Marsiglio, 2000; Stolz et al., 2005)과 일맥상통한다. 이 는 가정 내에서 어머니가 자신의 감정을 잘 통제하고 긍정적 인 방향으로 분위기를 전환할 수 있는 의도적 통제 능력은 어 머니 스스로의 양육행동을 긍정적으로 하도록 도울 뿐 아니라 아버지의 긍정적인 양육행동을 최대한 이끌어 낼 수 있는 중 요한 역할을 하는 것으로 해석할 수 있다.

위의 연구결과를 통해서, 아버지와 자녀가 함께 상호작용 하는 시간이 줄어들어 아버지의 영향력이 점차 감소될 수 있 는 학령기 후기 아동임에도 불구하고, 여전히 아버지의 양육 행동이 아동의 의도적 통제 발달을 예측하는 것을 확인하였 다. 특히, 아버지의 높은 수준의 의도적인 통제와 어머니의 의 도적인 통제는 아버지의 긍정적인 양육의 효과를 더욱 증가시 킬 수 있는 중요한 요인임을 알 수 있었다. 또한, 가정 내에서 아버지는 긍정적인 양육을 하는 것도 중요하지만 부정적인 양 육을 하지 않는 것이 더욱 중요하다는 점을 알 수 있었다. 즉, 아버지의 강압적이고 개입적인 양육행동은 아동의 의도적 통 제 발달을 방해하는 위험요인임을 알 수 있다. 한국 사회에서 아직 남아있는 권위주의적인 가부장적인 가족 분위기와 아버 지에 의한 체벌이나 학대와 같은 강압적인 양육행동을 하지 않도록 부모 교육 현장에서 아버지를 참여시키는 노력이 더욱 필요해 보인다. 또한, 부모에게 양육행동 기술 향상을 위한 일 반적 부모교육과 더불어 어머니 뿐 아니라 아버지의 의도적 통제를 함께 향상시킬 수 있는 정서조절 프로그램을 병행하는 것이 필요하며 아버지의 역할을 돕기 위해서는 어머니의 중간 다리 역할이 중요함을 강조하고, 아버지와 어머니의 공동 역
할을 강조하는 부모교육의 접근을 할수록 효과가 더욱 증대시 킬 것이라는 시사점이 있다.

본 연구의 제한점은 다음과 같다. 첫째, 본 연구에서는 횡단 적 자료만을 포함되었고, 부모보고에 의한 아동의 기질적인 의도적 통제 능력만 분석되어 아동의 자기 보고 조사와 행동 관찰을 위한 실험과제 등의 다양한 조사 방법이 포함되지 않 았다. 둘째, 어머니와 아버지의 의도적 통제 내적 신뢰도가 높 은 편은 아니었지만 $(\alpha=.79)$ 같은 측정도구(ATQ)를 사용한 국 내외 선행연구들이 보고한 신뢰도(.70 .82)(Bae \& Lim, 2012; Bridgett et al., 2013; De Panfilis, Meehan, Cain, \& Clarkin, 2013) 와 유사한 것으로 나타나 국내에서 사용하는 것에 무리가 없 다고 판단하였다. 하지만, 앞으로 국내 부모를 대상으로 이 측 정도구에 대한 추후연구가 반복적으로 조사될 필요가 있다. 이러한 제한점에도 불구하고, 본 연구는 의도적 통제 연구가 부족한 현 시점에서 국내외 선행연구들에서 밝히지 못했던 아 버지의 의도적 통제의 역할에 대한 근거를 마련하였다는데 의 의가 있다. 의도적 통제 성숙이 안정적으로 이루어지고 있는 학령기 아동에게도 아버지의 양육행동이 아동의 의도적 통제 에 영향을 미치고, 아버지의 의도적 통제 수준에 따라서 그 영 향이 조절되는 바를 확인하였다. 또한, 아버지 양육행동의 영 향력은 가정 내 어머니의 의도적 통제 능력에 의해 조절되는 효과를 밝혔다. 본 연구에서 고찰한 선행연구들(Bae \& Lim, 2012; Kim, 2015)과 본 연구 결과를 통해서, 가정 내에서 어머 니의 조절능력은 아동에게 직접적 혹은 양육을 통한 간접적인 영향을 미치고, 아버지의 긍정적인 양육 효과를 조절하는 역 할을 하는 중요한 요인임을 다시 한 번 확인하였다. 이에 반해, 아버지의 조절능력은 아동의 조절능력 발달에 기여하지 않는 것처럼 보여도 아버지의 양육에 의한 효과를 더 강하게 혹은 약하게 만드는 역할을 하고 있음을 확인하였다. 이렇듯 아버 지와 어머니의 개인적 특성인 의도적 통제가 가정 내 부모-자 녀 간에 고유한 영향을 미치고 있는지에 대한 추가적인 정보 를 마련하였다는데 의의가 있다. 본 연구는 부모교육 현장에 서 양육기술 교육의 효과를 극대화하기 위해서는 어머니와 아 버지 모두의 정서를 조절하는 훈련 전략이 필요하다는 근거를 마련하였다. 본 연구를 근거로, 아버지와 어머니의 의도적 통 제가 아동의 다양한 발달 영역에 미치는 영향을 조사하여 부 모의 영향력이 발달의 영역 특수적으로 차이가 나타나는지 비 교하거나, 혹은 아버지와 어머니의 의도적 통제와 부부 간의 상호작용 질 간의 관계를 조사하는 등 다양한 주제의 후속 연 구로 확장될 것을 기대한다. 


\section{Notes}

This article was poster presented at the 2016 Annual Fall Conference of the Korean Association of Child Studies.

\section{Conflict of Interest}

The authors declare that they have no conflict of interest.

\section{References}

\section{In English}

Aiken, L. S., \& West, S. G. (1991). Multiple regression: Testing and interpreting interactions. Newbury Park, CA: Sage.

Bariola, E., Hughes, E. K., \& Gullone, E. (2012). Relationships between parent and child emotion regulation strategy use: A brief report. Journal of Child and Family Studies, 21(3), 443-448. doi:10.1007/s10826-011-9497-5

Bridgett, D. J., Burt, N. M., Laake, L., \& Oddi, K. B. (2013). Maternal self-regulation, relationship adjustment, and home chaos: Contributions to infant negative emotionality. Infant Behavior and Development, 36(4), 534-547. doi:10.1016/ j.infbeh.2013.04.004

Bridgett, D. J., Gartstein, M. A., Putnam, S. P., Lance, K. O., Iddins, E., Waits, R., ... Lee, L. (2011). Emerging effortful control in toddlerhood: The role of infant orienting/regulation, maternal effortful control, and maternal time spent in caregiving activities. Infant Behavior and Development, 34(1), 189-199. doi:10.1016/j.infbeh.2010.12.008

Bronfenbrenner, U. (1986). Ecology of the family as a context for human development: Research perspectives. Developmental Psychology, 22(6), 723-742. doi:10.1037/0012-1649. 22.6.723

Calkins, S. D., \& Hill, A. (2007). Caregiver influences on emerging emotion regulation (Biological and environmental transactions in early development). In J. J. Gross (Ed.), Handbook of emotion regulation (pp. 229-268). New York, NJ: The Guilford press.

Cassano, M., Perry-Parrish, C., \& Zeman, J. (2007). Influence of gender on parental socialization of children's sadness regulation. Social Development, 16(2), 210-231. doi:10.1111/ j.1467-9507.2007.00381.x

Chang, L., Olson, S. L., Sameroff, A. J., \& Sexton, H. R. (2011). Child effortful control as a mediator of parenting practices on externalizing behavior: Evidence for a sex-differentiated pathway across the transition from preschool to school. Journal of Abnormal Child Psychology, 39(1), 71-81. doi:10.1007/s10802-010-9437-7

Day, R. D., \& Padilla-Walker, L. M. (2009). Mother and father connectedness and involvement during early adolescence. Journal of Family Psychology, 23(6), 900-904. doi:10.1037/ a0016438

De Panfilis, C., Meehan, K. B., Cain, N. M., \& Clarkin, J. F. (2013). The relationship between effortful control, current psychopathology and interpersonal difficulties in adulthood. Comprehensive Psychiatry, 54(5), 454-461. doi:10.1016/ j.comppsych.2012.12.015

Eisenberg, N., Chang, L., Ma, Y., \& Haung, X. (2009). Relations of parenting style to Chinese children's effortful control, ego resilience, and maladjustment. Development and Psychopathology, 21(2), 455-477. doi:10.1017/S09545794090 0025X

Eisenberg, N., Cumberland, A., Spinrad, T. L., Fabes, R. A., Shepard, S. A., Reiser, M., . . Guthrie, I. K. (2001). The relations of regulation and emotionality to children's externalizing and internalizing problem behavior. Child Development, 72(4), 1112-1134. doi:10.1111/1467-8624.00337

Eisenberg, N., \& Spinrad, T. L. (2004). Emotion-related regulation: Sharpening the definition. Child Development, 75(2), 334-339. doi:10.1111/j.1467-8624.2004.00674.x

Eisenberg, N., Valiente, C., Fabes, R. A., Smith, C. L., Reiser, M., Shepard, S. A., . . Cumberland, A. J. (2003). The relations of effortful control and ego control to children's resiliency and social functioning. Developmental Psychology, 39(4), 761-776. doi:10.1037/0012-1649.39.4.761

Eisenberg, N., Valiente, C., Spinrad, T. L., Cumberland, A., Liew, J., Reiser, M., . . L Losoya, S. H. (2009). Longitudinal relations of children's effortful control, impulsivity, and negative emotionality to their externalizing, internalizing, and cooccurring behavior problems. Developmental Psychology, 45(4), 988-1008. doi:10.1037/a0016213

Eisenberg, N., Zhou, Q., Spinrad, T. L., Valiente, C., Fabes, R. A., \& Liew, J. (2005). Relations among positive parenting, children's effortful control, and externalizing problems: A three-wave longitudinal study. Child Development, 76(5), 1055-1071. doi:10.1111/j.1467-8624.2005.00897

Evan, D. E. \& Rothbart, M. K. (2007). Developing a model for adult temperament. Journal of Research Perspective, 41(4), 868-888. doi:10.1016/j.jrp.2006.11.002

Fivush, R., Brotman, M. A., Buckner, J. P., \& Goodman, S. H. (2000). Gender differences in parent-child emotion narratives. Sex Roles, 42(3-4), 233-253. doi:10.1023/ A: 1007091207068

Garstein, M. A., \& Fagot, B. I. (2003). Parental depression, parenting and family adjustment, and child effortful 
control: Explaining externalizing behaviors for preschool children. Journal of Applied Developmental Psychology, 24(2), 143-177. doi:10.1016/S0193-3973(03)00043-1

Geng, F., Hu, Y., Wang, Y., \& Chen, F. (2011). Two types of behavioral inhibition: Relations to effortful control and attention in school children. Journal of Research in Personality, 45(6), 662-669. doi:10.1016/j.jrp.2011.09.005

Karreman, A., Van Tuijl, C., Van Aken, M. A., \& Deković, M. (2008). Parenting, coparenting, and effortful control in preschoolers. Journal of Family Psychology, 22(1), 30-40. doi:10.1037/0893-3200.22.1.30

Kochanska, G., \& Knaack, A. (2003). Effortful control as a personality characteristic of young children: Antecedents, correlates, and consequences. Journal of Personality, 71(6), 1087-1112. doi:10.1111/1467-6494.7106008

Lee, J., \& Chyung, Y.-J. (2014). Parental power-prestige and the effectsof paternal versus maternal acceptance on the psychological adjustment of Korean children. Cross-Cultural Research, 48(3), 259-269. doi:10.1177/1069397114528303

Lengua, L. J., Bush, N. R., Long, A. C., Kovacs, E. A., \& Trancik, A. M. (2008). Effortful control as a moderator of the relation between contextual risk factors and growth in adjustment problems. Development and Psychopathology, 20(2), 509-528. doi:10.1017/S0954579408000254

Los Reyes, A., Thomas, S. A., Goodman, S. A., \& Kundey, S. M. A. (2013). Principles underlying the use of multiple informants' reports. Annual Review of Clinical Psychology, 9, 123-149. doi:10.1146/annurev-clinpsy-050212-185617

Marsiglio, W., Amateo, P., Day, R. D., \& Lamb, M. E. (2000). Scholarship on fatherhood in the 1990s and beyond. Journal of Marriage and the Family. 62(4), 1173-1191. doi:10.1111/ j.1741-3737.2000.01173.x

McDowell, D. J., Kim, M., O'neil, R., \& Parke, R. D. (2002). Children's emotional regulation and social competence in middle childhood: The role of maternal and paternal interactive style. Marriage \& Family Review, 34(3-4), 345364. doi:10.1300/J002v34n03_07

McDowell, D. J., \& Parke, R. D. (2000). Differential knowledge of display rules for positive and negative emotions: Influence from parents, influences on peers. Social Development, 9(4), 415-432. doi:10.1111/1467-9507.00136

Mullineaux, P. Y., Deater-Deckard, K., Petrill, S. A., \& Thompson, L. A., (2009). Parenting and child behavioral problems: A longitudinal analysis of non-shared environment. Infant and Child Development, 18(2), 133-148. doi:10.1002/ icd. 593

Rothbart, M. K., Ahadi, S. A., \& Evans, D. E. (2000). Temperament and personality: Origins and outcomes. Journal of Personality and Social Psychology, 78(1), 122-135. doi:10.1037/0022-3514.78.1.122
Rothbart, M. K., \& Bates, J. E. (2006). Temperament. In N. Eisenberg \& W. Damon (Eds.), Handbook of Child Psychology: Social, emotional, and personality development (Vol 3., pp. 99-166). NY: Wiley.

Rothbart, M. K., \& Posner, M. I. (2005). Genes and experience in the development of executive attention and effortful control. New Directions for Child and Adolescent Development, 2005(109), 101-108. doi:10.1002/cd.142

Rothbart, M. K., \& Rueda, M. R. (2005). The development of effortful control. In U. Mayr, E. Awh, \& Keele (Eds.), Developing individuality in the human brain: A tribute to Michael, I. Posner (pp. 167-199). Washington, DC: American Psychological Association.

Shwalb, D. W., Nakazawa, J., Yamamoto, T., \& Hyun, J.-H. (2004). Fathering in Japanese, Chinese, and Korean cultures. In M. E. Lamb (Ed.), The role of the father in child development (4th ed., pp. 146-181). Hoboken, NJ: John Wiley \& Sons, Inc.

Simonds, J., Kieras, J. E., Rueda, M. R., \& Rothbart, M. K. (2007). Effortful control, executive attention, and emotional regulation in 7-10-year-old children. Cognitive Development, 22(4), 474-488. doi:10.1016/j.cogdev.2007.08.009

Simonds, J., \& Rothbart, M. K. (2004). The temperament in middle childhood questionnaire (TMCQ): A computerized selfreport instrument for ages 7-10. Poster presented at Occas Temperament Conference Athens, GA.

Spinrad, T. L., Eisenberg, N., Cumberland, A., Fabes, R. A., Valiente, C., Shepard, S. A., . . Guthrie, I. K. (2006). Relation of emotion-related regulation to children's social competence: A longitudinal study. Emotion, 6(3), 498-510. doi:10.1037/1528-3542.6.3.498

Stolz, H. E., Barber, B. K., \& Olsen, J. A. (2005). Toward disentangling fathering and mothers: An assessment of relative importance. Journal of Marriage and Family, 67(4), 1076-1092. doi:10.1111/j.1741-3737.2005.00195.x

Valiente, C., Eisenberg, N., Spinrad, T. L., Reiser, M., Cumberland, A., Losoya, S. H., \& Liew, J. (2006). Relations among mothers' expressivity, children's effortful control, and their problem behaviors: A four-year longitudinal study. Emotion, 6(3), 459-472. doi:10.1037/1528-3542.6.3.459

Valiente, C., Lemery-Chalfant, K., \& Reiser, M. (2007). Pathways to problem behaviors: Chaotic homes, parent and child effortful control, and parenting. Social Development, 16(2), 249-267. doi:10.1111/j.1467-9507.2007.00383.x

Verstraeten, K., Vasey, M. W., Raes, F., \& Bijttebier, P. (2009). Temperament and risk for depressive symptoms in adolescence: Mediation by rumination and moderation by effortful control. Journal of Abnormal Child Psychology, 37(3), 349-361. doi:10.1007/s10802-008-9293-x

White, L. K., McDermott, J. M., Degnan, K. A., Henderson, H. A., \& Fox, N. A. (2011). Behavioral inhibition and anxiety: 
The moderating roles of inhibitory control and attention shifting. Journal of Abnormal Child Psychology, 39(5), 735747. doi:10.1007/s10802-011-9490-x

Zhou, Q., Eisenberg, N., Wang, Y., \& Reiser, M. (2004). Chinese children's effortful control and dispositional anger/frustration: Relations to parenting styles and children's social functioning. Developmental Psychology, 40(3), 352-366. doi:10.1037/00121649.40.3.352

Zhou, Q., Hofer, C., Eisenberg, N., Reiser, M., Spinrad, T. L., \& Fabes, R. A. (2007). Developmental trajectories of attention focusing, attentional and behavioral persistence, and externalizing problems during school-age years. Developmental Psychology, 43(2), 369-385. doi:10.1037/0012-1649.43.2.369

\section{In Korean}

Bae, Y.-J., \& Lim, J.-Y. (2011). Analysis of trends in research on effortful control. Korean Journal of Human Ecology, 20(1), 57-70. doi:10.5934/KJHE.2011.20.1.057

Bae, Y.-J., \& Lim, J.-Y. (2012). Relations between parents' effortful control, parenting behavior and infants' effortful control. Journal Korean Home Economics Assoociation, 50(2), 53-64. doi:10.6115/khea.2012.50.2.053

Bae, Y.-J., \& Lim, J.-Y. (2015). The mediating effect of effortful control on the relationship between affectionate parenting behavior and preschooler's conscience. Korean Journal of Child Studies, 36(1), 47-64. doi:10.5723/KJCS.2015.36.1.47

Kim, J. H. (2015). The influence of mother's and father's effortful control and parenting behaviors on child's school adjustment mediated by child's effortful control (Doctoral dissertation). Retrieved from http://www.riss.kr/link?id=T13819105

Lim, J.-Y., Lee, Y.-J., \& Bae, Y.-J. (2015). The influence of coparenting in two-parent families on preschooler's effortful control mediated by parenting behaviors. Journal of Family Relations, 20(3), 65-92.

Ministry of Gender Equality and Family. (2016). 2015 factfinding survey on families: Relationship between adolescence and mothers or fathers in Korea. Retrieved from Korean Statistical Information Service website: http://kosis.kr

Rhee, S. H., \& Doh, H.-S. (2012). The development and validation of a parenting behavior scale for parents of early school-age children. Korean Journal of Child Studies, 35(6), 111-133. doi:10.5723/KJCS.2014.35.6.111

\section{ORCID}

$\begin{array}{ll}\text { Jae Hee Kim } & \text { http://orcid.org/0000-0002-3427-9201 } \\ \text { Hyoun K. Kim } & \text { http://orcid.org/0000-0002-2963-9954 } \\ \text { Heesun Lee } & \text { http://orcid.org/0000-0003-4037-3955 }\end{array}$

Received April 30, 2017 Revision received May 31, 2017 Accepted June 16, 2017 